\title{
INFLUENCE OF VARIETIES AND SEEDING RATES ON GROWTH, PRODUCTIVITY, DISEASE REACTION AND ECONOMICS OF WHEAT IN NORTHWEST INDIA
}

\author{
H. Ram ${ }^{1}$, G. S. Buttar ${ }^{1}$, I. Bhagat ${ }^{1}$, I. Sharma ${ }^{2}$, G. S. Mavi ${ }^{1}$ and M. M. Jindal ${ }^{1}$
}

\begin{abstract}
The field experiment on influence of varieties and seeding rates on growth, productivity, disease reaction and economics of wheat was conducted at the Punjab Agricultural University, Ludhiana, India and its regional stations Bathinda and Gurdaspur in 2007-08 to 2008-09. The experiment was conducted in split plot design with three varieties, PBW 550, PBW 343 and $D B W 17$ as main plot treatments and four seed rates, 87.5, 100, 112.5 and $125 \mathrm{~kg} / \mathrm{ha}$ as sub plot treatments having four replications. The highest ears $/ \mathrm{m}^{2}$ was recorded in variety $P B W 343$ which was significantly higher than DBW 17 at Bathinda and Gurdaspur but not at Ludhiana. The highest grains/ear were recorded in variety $P B W 550$ which was significantly higher than $P B W 343$ and $D B W$ 17. The yellow rust score of variety PBW 343 was $80 S$ at Gurdaspur and $60 S$ at Ludhiana which was epidemic year for yellow rust but PBW 550 and DBW 17 show almost similar response to yellow rust (5S to $20 \mathrm{MS}$ ). The significantly higher productivity was recorded in PBW 550 at all the locations in all the years except in Ludhiana Increased seed rate, increased the plant stand, photosynthetically active radiation interception and leaf area index. The highest ears $/ \mathrm{m}^{2}$ was recorded in seed rate of $125 \mathrm{~kg} / \mathrm{ha}$ which was statistically on par with seed rate of $112.5 \mathrm{~kg}$ seed/ha but was significantly higher than seed rate of 87.5 and $100 \mathrm{~kg} / \mathrm{ha}$. There was no trend for different diseases with respect to seed rate. The highest productivity was recorded in $112.5 \mathrm{~kg}$ seed rate/ha which was significantly higher than all the other seed rates. The highest grain yield of PBW 550 at seed rate of $112.5 \mathrm{~kg} / \mathrm{ha}$ was statistically on par with only PBW 550 at $125 \mathrm{~kg}$ seed rate/ha but significantly higher than all the other varieties at all the seed rates. The highest gross, net returns and $B: C$ ratio recorded in $P B W 550$ at $112.5 \mathrm{~kg}$ seed rate/ha.
\end{abstract}

Keywords: disease reaction, productivity, seed rates, wheat varieties

\section{INTRODUCTION}

Wheat is the second most important cereal in India after rice, contributing substantially to the national food security by providing more than $50 \%$ of the calories to the people who mainly depend on it. India has witnessed a significant increase in wheat production with 93.9 million tonnes during 2011-12 (Anonymous, 2012). The scenario for the past ten years has clearly indicated that the wheat production in India has soared ahead despite the land area remaining the same. The population growth rate in the Indo-Gangetic Plains of India is still about $2 \%$ per year and will take a few decades to stabilize. It is estimated that about $2.5 \%$ growth in cereal production will be required to meet food demands in the next decade. During the past 30 years, agricultural production has been able to keep pace with population demand for food.

\footnotetext{
1 Punjab Agricultural University, Ludhiana, Punjab, India 141004.

2 Directorate of Wheat Research Karnal, Punjab, India.
} 
Indo-Gangetic plains are the primary producer of wheat in India with 2.9 million ha planted in 2011. The varietal selection, seeding rate, weed management, irrigation management and nitrogen $(\mathrm{N})$ management are key factors for wheat growers to achieve maximum economic returns. These management factors may interact with new varieties that have different morphological characteristics, seed size and tillering habits. The selection of variety plays a very important role in determining grain yield of wheat. Genotypes vary widely in yield potential and agronomic traits (Fowler et al., 1990, Coventry et al., 1993). The seed rate plays an important role to capture the resources. Depending on the environmental conditions, soil, sowing time and genotypes, seeding rate can have a great impact on wheat tillering and grain yield. Coventry et al., (1993) and Staggenborg et al., (2003) reported that higher seeding rates compensate for low tillering and promote more main stem spikes which can be favourable, especially to the varieties that produce less tillers like variety PBW 550. In Belgium and northern France, the optimum spike densities of wheat ranged from 475 to 500 spikes $/ \mathrm{m} 2$ and are normally obtained from target density of 200 plants/ $\mathrm{m}^{2}$. Wiersma (2002) however, emphasized that varieties differ genetically for yield components and yield and the variety should be tested at different populations to determine their optimum seeding rates. The varieties have different abilities to compensate for low or high plant populations by modifying the number of tillers and consequently the number of spikes $/ \mathrm{m}^{2}$, the number of kernels/ spike or the grain weight. The recommended seed rate for wheat to achieve maximum grain yield is $100 \mathrm{~kg} \mathrm{seed} / \mathrm{ha}$ in India (Anonymous, 2010). Staggenborg et al., (2003) reported inconsistent winter wheat grain yield responses to seeding rate, which was highly dependent on environmental conditions. However, limited information regarding the effects of intensive management on wheat yield has been published. Keeping these points in mind, the present investigations were conducted to determine the influence of varieties and seeding rates on growth, productivity, disease reaction and economics of wheat at different locations under Indian Punjab conditions

\section{MATERIALS AND METHODS}

The field experiment on influence of seed rate on productivity and disease reaction of different varieties of wheat was conducted at the Punjab Agricultural University, Ludhiana and its regional stations Bathinda and Gurdaspur in 2007-08 and 2008-09. The experiment was conducted in a split plot design with three varieties, PBW 550, PBW 343 and DBW 17 as main plot treatments and four seed rates, 87.5, $100,112.5$ and $125 \mathrm{~kg} / \mathrm{ha}$, as sub plot treatment having four replications at all the locations. The Ludhiana's experimental site $\left(30^{\circ} 56^{\prime} \mathrm{N}\right.$, $75^{\circ} 52^{\prime} \mathrm{E} ; 247 \mathrm{~m}$ ASL), had a deep alluvial loamy sand, low in organic carbon $(3.3 \mathrm{~g} \mathrm{C} /$ $\mathrm{kg}$ ) and slightly alkaline ( $\mathrm{pH} 7.5)$. The regions also have sub-tropical climates with cool and dry winters in the crop season (Table 01). At Bathinda, the soils was loamy sand having low organic carbon $(0.21 \mathrm{~g} \mathrm{C} / \mathrm{kg})$ and nitrogen $(175.5 \mathrm{~kg} / \mathrm{ha})$ whereas medium in available phosphorus $(22.0 \mathrm{~kg} / \mathrm{ha})$ and high in available potassium (165 kg/ha). At Gurdaspur, the soils was loamy having medium in organic carbon (0.42 g C/kg), phosphorus (21.2 kg/ha) and high in available potassium (160 kg/ha). This region also has sub-humid climates with cool and wet winters in the crop season. 
Table 01: Meteorological data of different location of experimentation.

\begin{tabular}{|c|c|c|c|c|c|c|c|}
\hline \multirow{2}{*}{ Parameter } & \multicolumn{7}{|c|}{ Months } \\
\hline & October & November & December & January & February & March & April \\
\hline & \multicolumn{7}{|c|}{ Ludhiana (2007-08) } \\
\hline Min. Temp. $\left({ }^{\circ} \mathrm{C}\right)$ & 15.2 & 11.2 & 5.7 & 4.5 & 6.4 & 14.0 & 17.7 \\
\hline Max. Temp. $\left({ }^{\circ} \mathrm{C}\right)$ & 32.5 & 27.5 & 19.9 & 16.9 & 20.2 & 30.4 & 34.1 \\
\hline Rainfall (mm) & 0 & 1.3 & 17.7 & 16.3 & 3.2 & 0 & 50.2 \\
\hline \multirow[t]{2}{*}{ Mean RH (\%) } & 62 & 64 & 75 & 71 & 72 & 65 & 48 \\
\hline & \multicolumn{7}{|c|}{ Ludhiana (2008-09) } \\
\hline Min. Temp. $\left({ }^{\circ} \mathrm{C}\right)$ & 19.3 & 27.6 & 21.2 & 19.6 & 23.3 & 28.9 & 35.2 \\
\hline Max. Temp. $\left({ }^{\circ} \mathrm{C}\right)$ & 31.7 & 11.1 & 8.6 & 7.7 & 9.1 & 13 & 17.6 \\
\hline Rainfall (mm) & 39 & 0.4 & 4 & 79 & 1.6 & 0.5 & 59 \\
\hline \multirow[t]{2}{*}{ Mean RH (\%) } & 69 & 66 & 78 & 0.6 & 74 & 65 & 0.8 \\
\hline & \multicolumn{7}{|c|}{ Bathinda (2007-08) } \\
\hline Min. Temp. $\left({ }^{\circ} \mathrm{C}\right)$ & 14.1 & 14.5 & 5.5 & 3.0 & 3.9 & 12.7 & 17.2 \\
\hline Max. Temp. $\left({ }^{\circ} \mathrm{C}\right)$ & 32.1 & 28.9 & 20.5 & 16.9 & 20.4 & 31.2 & 35.2 \\
\hline Rainfall (mm) & 0.0 & 2.4 & 9.0 & 4.4 & 2.8 & 0.0 & 39.6 \\
\hline Mean RH (\%) & 56.2 & 65.0 & 67.8 & 67 & 65.7 & 59.7 & 63 \\
\hline
\end{tabular}

The crop was sown in second week of November at all the locations at inter-row spacing of $22.5 \mathrm{~cm}$. The nitrogen dose of 75 $\mathrm{kg}$ and phosphorus dose of $60 \mathrm{P}_{2} \mathrm{O}_{5}$ per hectare were applied at the time of sowing and the remaining $75 \mathrm{~kg} \mathrm{~N} /$ ha was applied at the time of first irrigation i.e. 30-32 days after sowing at Ludhiana and Bathinda locations. However, at Gurdaspur the dose of nitrogen was $60 \mathrm{Kg}$ $\mathrm{N} / \mathrm{ha}+60 \mathrm{~kg} \mathrm{P}_{2} \mathrm{O}_{5} / \mathrm{ha}$ was applied at sowing and $60 \mathrm{~kg} \mathrm{~N} / \mathrm{ha}$ applied at 32 days after sowing after first irrigation. The total rainfall of 88.7 $\mathrm{mm}$ and $183.5 \mathrm{~mm}$ was received at Ludhiana in 2007-08 and 2008-09 years respectively. The rainfall received at Bathinda and Gurdaspur was 58.2 and $63.2 \mathrm{~mm}$ respectively in 2007 08. The crop received four irrigations at all the locations during 2007-08 but during 200809 at Ludhiana only three irrigations were applied. The herbicides (isoproturon at $1 \mathrm{~kg}$ / ha $+2,4-\mathrm{D}$ at $0.62 \mathrm{~kg} / \mathrm{ha}$ ) were applied as tank mix application after first irrigation to control wild oats and other broad leaf weeds. The germination count data were collected 20 days after sowing from one metre row length which were presented as plant stand per $\mathrm{m}^{2}$. The data on photosynthetically active radiation (PAR) were recorded at 90 days after sowing with Line quantum sensor (LI-COR photometer model LI-191-SA, Nebraska, USA) which has quantum (photon) response through wavelength range of 400-700 nm for PPFD (photosynthetic Photon Flux Density). The following formula was used to calculate PAR interception (Ram et al., 2012).

$$
\text { PARI }(\%)=\frac{\begin{array}{c}
\text { PAR above the crop canopy }- \text { PAR } \\
\text { at soil surface }
\end{array}}{\text { PAR above the crop canopy }} \times 100
$$

The plants of a randomly selected $0.25 \mathrm{~m}$ row length from two spots per plot were harvested and their leaf area was measured using leaf area meter (Delta T Image Analyzer, Burwell Cambridge, UK) and presented as leaf area index (LAI = Leaf area / ground area). The data on yellow rust (Puccinia striiformis) and powdery mildew (Erysiphe graminis f.sp. tritici) was collected on $15^{\text {th }}$ of March at all the locations. The severity of yellow rust disease was scored following a modified 
Cobb's scale (Petersen et al., 1948). Both $\%$ leaf area infected (severity) and type of pustules (response) are considered for rating. Data on powdery mildew was based on $0-9$ scale where 9 represents the highest score when visually the powdery mildew infection is at earheads also affecting awns whereas 0 indicates no disease and corresponding to growth stage starting from appearance of disease from lower leaves is score 1 and score is 2 when disease appear on next leaves and so on and so forth the numerical value exceeds (Bennett and Westcott, 1982). The crop was harvested manually at maturity (14-20 April) and threshed with an engine operated thresher. The ear head density was recorded from a one metre row length at two spots per plot and converted to on area basis. Ten ears were collected randomly from the plot and threshed manually to calculate grains/ear. During threshing, samples were collected from each plot to determine the 1000-grain weight data. The observations on biomass and grain yield were collected at the time of harvest from net plot of $14.0 \mathrm{~m}^{2}$. The data on per cent infection of black point and Karnal bunt (Tilletia indica) were collected after threshing from the grains of each plot. Karnal bunt infection was recorded as per method of Sharma et al., (1998) and black point as per method given by Chaudhary, et al., (1985). The random sample of $250 \mathrm{~g}$ was obtained from each replication after harvesting. From each sample black point and Karnal bunt infected grains were counted out of 2000 grains from each lot and $\%$ infection worked out. In case of Karnal bunt infection the infection visually appear as blackening at germinal tip which extends to grooves and in case of high infection the $3 / 4^{\text {th }}$ or the whole grain shows blackening. The blackening is due to teliospores present inside the pericarp. On rupturing such grains, black powdery mass comes out. In case of black point there is discolouration (dark brown colour) at the dorsal side of germinal end which may extend further affecting not more than $1 / 4^{\text {th }}$ of the grain. No spore mass is there in case of black point infected grains. The gross income and variable costs were calculated on the basis of market price for various inputs and wheat produce at the time of harvest in each year. The net returns were calculated by subtracting variable costs from the gross income. The variable costs include all the costs involved in inputs and all farm operations. The B:C (benefit: cost) ratio was calculated by dividing net returns with variable costs. The data were analyzed using standard method of ANOVA for split plot design.

\section{RESULTS AND DISCUSSION}

\section{Plant stand}

The plant stand was significantly influenced by wheat varieties as well as seed rates in both years of study (Table 02). The highest plant stand was recorded in PBW 343 \& which was statistically on par with DWR 17 but significantly higher than PBW 550. There was no significant difference between PBW 550 and DBW 17 during both the years of study. This might be due to varietal characters. Increase in seed rate, increased the plant stand in both years of study. The highest plant stand was recorded in $125 \mathrm{~kg}$ seed/ha which was significantly higher than all the other seed rates. With increasing seed rate there was a significant increase in plant stand in both the years of study. It is be due to higher seeds sown/unit area.

\section{$P A R$ interception and leaf area index}

The PAR interception is an important parameter which depicts the radiation use efficiency of the crop (Table 02). The variety PBW 343 recorded the highest PAR interception and LAI which was significantly higher than both the other varieties i.e. DBW 17 and PBW 550 in the to years of study. However, the variety DBW 17 and PBW 550 were not significantly different from each other. The higher PAR interception in variety PBW 343 might be due 
to higher leaf area index. Variation for PAR interception and LAI among varieties was also reported by Saleem et al., (2010). The seed rate also significantly influenced the PAR interception and LAI in both the years. The increase in PAR interception was recorded upto the highest seed rate of $125 \mathrm{~kg} / \mathrm{ha}$ which was significantly higher than all the seed rates except $112.5 \mathrm{~kg} \mathrm{seed} / \mathrm{ha}$ in 2008-09. The highest LAI was again recorded in $125 \mathrm{~kg} / \mathrm{ha}$ which was significantly higher than all other seed rate except $112.5 \mathrm{~kg} / \mathrm{ha}$ in 2008-09.

\section{Ears per square metre}

The highest ears $/ \mathrm{m}^{2}$ were recorded in variety PBW 343 which was statistically on par with DBW 17 at Ludhiana but significantly higher than DBW 17 at Bathida and Gurdaspur (Table 03). It might be due to varietal characters. The minimum ears per square metre were recorded in variety PBW 550 which was significantly lower than both varieties at all the locations. It might be due to shy tillering nature of variety PBW 550. Higher effective tillers in variety PBW 343 was also recorded by Bhardwaj et al., (2010).

The seed rate significantly influenced the ears $/ \mathrm{m}^{2}$ which was highest in $125 \mathrm{~kg}$ seed rate which was statistically on par with $112.5 \mathrm{~kg}$ seed rate but was significantly higher than 87.5 and $100 \mathrm{~kg}$ seed rate/ha. The minimum ears in $87.5 \mathrm{~kg}$ seed rate might be due to lower number of seed sown per square metre (Table 03). The interaction effect on the ears/ $\mathrm{m}^{2}$ were significant in 2007-08 at Ludhiana (Table 04). The variety PBW 550 at $112.5 \mathrm{~kg} /$ ha seed rate recorded significantly higher ears/ $\mathrm{m}^{2}$ than seed rate of 87.5 and $100 \mathrm{~kg}$ seed rate/ha but statistically on par with $125 \mathrm{~kg}$ seed rate. Low seed rates decrease interplant competition especially during vegetative growth, but increase intra plant competition during grain filling because plants tend to produce more spike-bearing tillers (Marshall and Ohm, 1987). Thus, generally, low seed rates increase the number of spikes produced by each plant and the weight of single spikes, but decrease the number of spikes per unit land, whereas the opposite occurs with high seed rates (Tompkins et al., 1991). Whaley et al., (2000) found that the number of kernels per spike increased by $50 \%$ in wheat plants when crop density decreased from 338 to 19 plants $/ \mathrm{m}^{2}$, but less than $10 \%$ increases were reported by Ozturk et al., (2006) when seed rate was decreased from 625 to $325 \mathrm{seeds} / \mathrm{m}^{2}$.

Table 02: Effect of seed rates on plant stand, PARI and LAI of wheat varieties at Ludhiana

\begin{tabular}{lcccccc}
\hline Treatment & \multicolumn{2}{c}{ Plant stand $/ \mathrm{m}^{2}$} & \multicolumn{2}{c}{$\begin{array}{c}\text { PAR interception (\%) } \\
\text { (90 DAS) }\end{array}$} & \multicolumn{2}{c}{ LAI } \\
& & \multicolumn{9}{c}{ (90 DAS) } \\
& $2007-08$ & $2008-09$ & $2007-08$ & $2008-09$ & $2007-08$ & $2008-09$ \\
\hline Varieties & & & & & & \\
PBW 550 & 211 & 208 & 88.4 & 90.4 & 2.78 & 2.88 \\
PBW 343 & 222 & 220 & 92.9 & 95.5 & 2.95 & 3.08 \\
DBW 17 & 217 & 213 & 87.2 & 90.2 & 2.81 & 2.80 \\
LSD(p=0.05) & 8 & 9 & 1.5 & 1.4 & 0.12 & 0.11 \\
Seed rate (kg/ha) & & & & & & \\
87.5 & 172 & 168 & 83.2 & 90.0 & 2.66 & 2.75 \\
100.0 & 203 & 194 & 85.3 & 91.4 & 2.73 & 2.85 \\
112.5 & 230 & 233 & 88.1 & 93.2 & 2.89 & 2.99 \\
125.0 & 262 & 260 & 89.4 & 93.5 & 3.11 & 3.10 \\
LSD(p=0.05) & 10 & 11 & 0.13 & 1.6 & 0.12 & 0.13 \\
Interaction & NS & NS & NS & NS & NS & NS \\
\hline
\end{tabular}




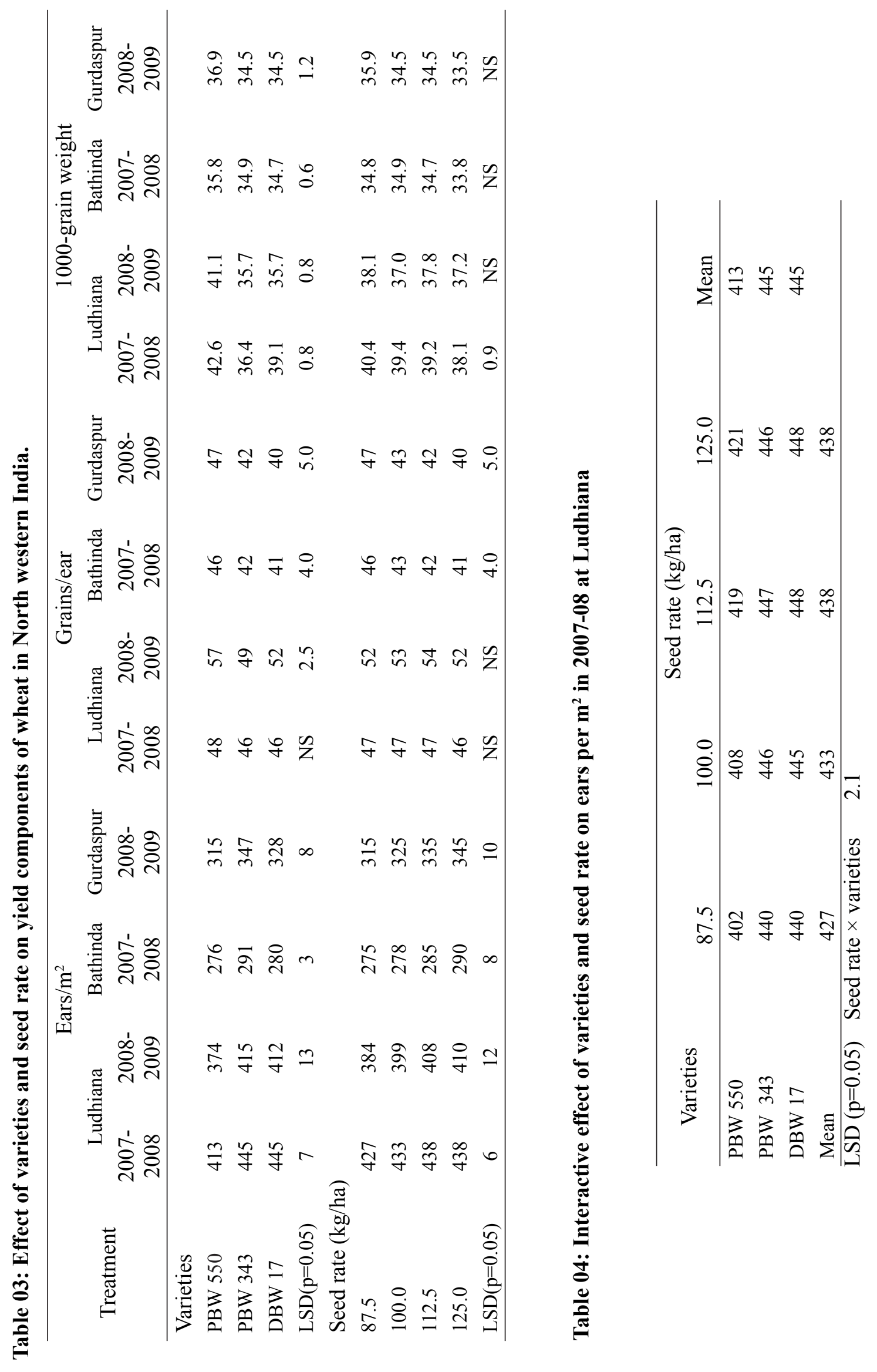




\section{Grains per ear}

The highest grains/ear were recorded in variety PBW 550 which was significantly higher than PBW 343 and DBW 17 at all the locations except in 2007-08 at Ludhiana but the trend was same (Table 3). The variety PBW 550 recorded about $10 \%$ higher grains/ear than other two varieties. DBW 17 and PBW 343 were statistically on par with each other for grains/ear except for year 2008-09 at Ludhiana where DBW 17 recorded significantly higher grains/ear than PBW 343. Arduini et al., (2009) and Lloveras et al., (2004) also recorded different number of grains per ear in different varieties of durum wheat.

The seed rate could not influence grains/ ear at Ludhiana. However, at Bathinda and Gurdaspur the highest grains/ear were recorded in $87.5 \mathrm{~kg}$ seed rate/ha which was statistically on par with 100 and $112.5 \mathrm{~kg}$ seed rate/ha but significantly higher than $125 \mathrm{~kg}$ seed rate/ha.

\section{0-grain weight}

The highest 1000-grain weight was recorded in variety PBW 550 which was significantly higher than in PBW 343 and DBW 17 varieties (Table 03). This is an important character of PBW 550 which compensated the ears $/ \mathrm{m}^{2}$ for the grain yield. The variety PBW 343 recorded significantly lower 1000-grain weight than DBW 17 at Ludhiana in 2007-08. It is well known that 1000-grain weight tends to be characteristic of a variety and there are large differences between varieties (Hobbs and Sayre, 2001).

The 1000-grain weight was highest in the seed rate of $87.5 \mathrm{~kg} / \mathrm{ha}$ which was significantly higher than others at Ludhiana in 2007-08 but the results were non-significant in other years and at other locations.

\section{Yellow rust incidence}

The incidence of yellow rust was ranged from
$5 \mathrm{~S}$ to $10 \mathrm{~S}$ in year $2007-08$ at all the locations but in 2008-09, the yellow rust score of variety PBW 343 goes to $80 \mathrm{~S}$ at Gurdaspur and $60 \mathrm{~S}$ at Ludhiana which was an epidemic year for yellow rust (Table 05). Singh et al., (2009) also reported similar observation of higher yellow rust in year 2008-09 in submountaineous region of the Indian Punjab. However, the varieties PBW 550 and DBW 17 show almost similar response to yellow rust. The yellow rust score at Gurdaspur was slightly higher when compared to Ludhiana due to more relative humidity in the submountaneous areas. The yellow rust score was comparatively low at Bathinda; it might be due to the fact that location is a drier part of the Punjab.

\section{Powdery mildew, black point and karnal bunt}

The data on powdery mildew, black point and karnal bunt have been presented in Table 06 . The powdery mildew and black point were lowest in variety PBW 550 when compared to other varieties. However the Karnal bunt was not found in both years except in variety DBW 17 in 2008-09. There was no trend for different diseases with respect to seed rate. However, Tompkins et al., (1992) reported that high seeding rate, can increase severity of powdery mildew.

\section{Crop productivity}

The crop productivity was significantly influenced by the varieties except at Ludhiana for 2007-08 (Table 07). The highest grain yield was recorded in PBW 550 at all the locations and in all the years except at Ludhiana but in other years and at other locations it was significantly higher than PBW 343 and DBW 17. The higher grain yield in PBW 550 might be due to higher number of grains/ear and higher 1000-grain weight. At Gurdaspur, the yield of PBW 343 was lowest because this area is near Shivalik hills and it is a hot spot for the yellow rust as reported by Aujla 
et al., (1986). The rust incidence was at its grain yield of varieties PBW 343 and DBW 17 maximum during 2008-09 at this location. The was statistically on par with each other.

Table 05: Effect of varieties and seed rates on yellow rust score at various locations in Indian Punjab

\begin{tabular}{lcccc}
\hline \multirow{2}{*}{ Varieties } & \multicolumn{4}{c}{ Seed rate $(\mathrm{kg} / \mathrm{ha})$} \\
& 87.5 & \multicolumn{4}{c}{100.0} & 112.5 & 125.0 \\
\hline & & \multicolumn{2}{c}{ Ludhiana } & $(2007-08)$ \\
PBW 550 & $5 \mathrm{~S}$ & $10 \mathrm{MS}$ & $10 \mathrm{MS}$ & $10 \mathrm{MS}$ \\
PBW 343 & $10 \mathrm{~S}$ & $10 \mathrm{~S}$ & $10 \mathrm{~S}$ & $10 \mathrm{~S}$ \\
DBW 17 & $10 \mathrm{MS}$ & $10 \mathrm{MS}$ & $10 \mathrm{MS}$ & $10 \mathrm{MS}$ \\
& & Ludhiana & $(2008-09)$ & \\
PBW 550 & $5 \mathrm{~S}$ & $20 \mathrm{MS}$ & $10 \mathrm{MS}$ & $20 \mathrm{MS}$ \\
PBW 343 & $60 \mathrm{~S}$ & $60 \mathrm{~S}$ & $60 \mathrm{~S}$ & $60 \mathrm{~S}$ \\
DBW 17 & $20 \mathrm{MS}$ & $20 \mathrm{MS}$ & $10 \mathrm{MS}$ & $20 \mathrm{MS}$ \\
& & Bathinda $(2007-08)$ & \\
PBW 550 & $5 \mathrm{~S}$ & $5 \mathrm{MS}$ & $5 \mathrm{MS}$ & $10 \mathrm{MS}$ \\
PBW 343 & $5 \mathrm{~S}$ & $5 \mathrm{~S}$ & $5 \mathrm{~S}$ & $5 \mathrm{~S}$ \\
DBW 17 & $5 \mathrm{MS}$ & $5 \mathrm{MS}$ & $5 \mathrm{MS}$ & $10 \mathrm{MS}$ \\
& & Gurdaspur $(2008-09)$ & \\
PBW 550 & $10 \mathrm{MS}$ & $20 \mathrm{MS}$ & $20 \mathrm{MS}$ & $20 \mathrm{MS}$ \\
PBW 343 & $80 \mathrm{~S}$ & $80 \mathrm{~S}$ & $80 \mathrm{~S}$ & $80 \mathrm{~S}$ \\
DBW 17 & $20 \mathrm{MS}$ & $20 \mathrm{MS}$ & $20 \mathrm{MS}$ & $20 \mathrm{MS}$ \\
\hline
\end{tabular}

Table 06:Effect of seed rate on disease incidence of wheat varieties at Ludhiana

\begin{tabular}{|c|c|c|c|c|c|}
\hline \multirow{2}{*}{ Treatment } & \multicolumn{2}{|c|}{ Powdery mildew } & \multicolumn{2}{|c|}{ Black point (\%) } & \multirow{2}{*}{$\begin{array}{c}\text { Karnal bunt (\%) } \\
2008-09 \\
\end{array}$} \\
\hline & 2007-08 & 2008-09 & $2007-08$ & 2008-09 & \\
\hline \multicolumn{6}{|l|}{ Varieties } \\
\hline PBW 550 & 4 & 5 & 0.3 & 0.4 & (1) \\
\hline PBW 343 & 7 & 9 & 1.9 & 2.1 & (1) \\
\hline DBW 17 & 7 & 9 & 1.5 & 1.6 & $0.02(1)$ \\
\hline $\operatorname{LSD}(\mathrm{p}=0.05)$ & 2 & 3 & 0.2 & 0.2 & NS \\
\hline \multicolumn{6}{|c|}{ Seed rate $(\mathrm{kg} / \mathrm{ha})$} \\
\hline 87.5 & 6 & 7.7 & 0.9 & 1.1 & $0 \quad(1)$ \\
\hline 100.0 & 6 & 7.7 & 1.8 & 1.9 & $0.01(1)$ \\
\hline 112.5 & 6 & 7.7 & 0.8 & 1.2 & $0.01(1)$ \\
\hline 125.0 & 6 & 7.7 & 1.3 & 1.2 & $0 \quad(1)$ \\
\hline $\operatorname{LSD}(p=0.05)$ & NS & NS & 0.3 & 0.3 & NS \\
\hline
\end{tabular}

Figures in parentheses are square root transformed values 
Table 07. Effect of varieties and seed rate on grain yield (tonnes/ha) of wheat at different locations

\begin{tabular}{|c|c|c|c|c|c|}
\hline \multirow{2}{*}{ Varieties } & \multicolumn{5}{|c|}{ Seed rate $(\mathrm{kg} / \mathrm{ha})$} \\
\hline & 87.5 & 100.0 & 112.5 & 125.0 & Mean \\
\hline & \multicolumn{5}{|c|}{ Ludhiana (2007-08) } \\
\hline PBW 550 & 6.13 & 6.15 & 6.54 & 6.31 & 6.29 \\
\hline PBW 343 & 6.18 & 6.41 & 6.14 & 6.24 & 6.24 \\
\hline DBW 17 & 5.99 & 6.20 & 6.06 & 6.21 & 6.12 \\
\hline \multirow[t]{2}{*}{ Mean } & 6.10 & 6.25 & 6.25 & 6.25 & \\
\hline & \multicolumn{5}{|c|}{ Ludhiana (2008-09) } \\
\hline PBW 550 & 6.08 & 6.22 & 6.94 & 6.88 & 6.53 \\
\hline PBW 343 & 5.08 & 5.50 & 5.43 & 5.39 & 5.35 \\
\hline DBW 17 & 5.50 & 5.50 & 5.74 & 5.74 & 5.62 \\
\hline \multirow[t]{2}{*}{ Mean } & 5.55 & 5.74 & 6.04 & 6.00 & \\
\hline & \multicolumn{5}{|c|}{ Bathinda (2007-08) } \\
\hline PBW 550 & 3.66 & 3.98 & 4.13 & 3.90 & 3.92 \\
\hline PBW 343 & 3.35 & 3.94 & 3.82 & 3.83 & 3.74 \\
\hline DBW 17 & 3.65 & 4.07 & 3.87 & 3.87 & 3.87 \\
\hline \multirow[t]{2}{*}{ Mean } & 3.55 & 4.00 & 3.94 & 3.87 & \\
\hline & \multicolumn{5}{|c|}{ Gurdaspur (2008-09) } \\
\hline PBW 550 & 3.34 & 4.79 & 5.64 & 5.54 & 4.83 \\
\hline PBW 343 & 3.31 & 2.54 & 5.24 & 2.69 & 3.45 \\
\hline DBW 17 & 3.29 & 4.53 & 4.55 & 4.61 & 4.25 \\
\hline \multirow[t]{2}{*}{ Mean } & 3.31 & 3.85 & 4.24 & 4.28 & \\
\hline & \multicolumn{5}{|c|}{ Pooled mean } \\
\hline PBW 550 & 4.80 & 5.29 & 5.81 & 5.66 & 5.39 \\
\hline PBW 343 & 4.48 & 4.60 & 5.16 & 4.54 & 4.70 \\
\hline DBW 17 & 4.61 & 5.08 & 5.06 & 5.11 & 4.97 \\
\hline Mean & 4.63 & 4.99 & 5.34 & 5.10 & \\
\hline \multirow[t]{2}{*}{$\operatorname{LSD}(p=0.05)$} & \multicolumn{2}{|c|}{ Ludhiana } & Bathinda & Gurdaspur & Pooled \\
\hline & $2007-08$ & 2008-09 & $2007-08$ & 2008-09 & \\
\hline Varieties & NS & 0.17 & 0.12 & 0.36 & 0.25 \\
\hline Seed rate & NS & 0.19 & 0.15 & NS & 0.21 \\
\hline Interaction & 0.34 & 0.33 & NS & NS & 0.25 \\
\hline
\end{tabular}

The seed rate significantly influenced the grain yield of wheat except in 2007-08 at Ludhiana. In 2008-09, at Ludhiana, it was the highest in $112.5 \mathrm{~kg} /$ ha which was statistically on par with $125 \mathrm{~kg}$ seed /ha but significantly higher than 87.5 and $100 \mathrm{~kg}$ seed rate/ha. At Bathinda, the highest grain yield was recorded in $100 \mathrm{~kg}$ seed rate/ha which was significantly higher than
$87.5 \mathrm{~kg} / \mathrm{ha}$ but statistically on par with 112.5 and $125 \mathrm{~kg} / \mathrm{ha}$. Gurdaspur the highest grain yield was recorded with $125 \mathrm{~kg} / \mathrm{ha}$ which was significantly higher than 87.5 and $100 \mathrm{~kg}$ seed rate/ha but statistically on par with $112.5 \mathrm{~kg}$ seed rate/ha. However on a pooled mean basis, the highest grain yield was recorded in 112.5 $\mathrm{kg}$ seed rate/ha which was significantly higher 
than all the other seed rates under study. The lower grain yield in 87.5 and $100 \mathrm{~kg}$ seed rate/ ha might be due to a lower plant stand in these treatments (Table 02). The lower grain yield in $125 \mathrm{~kg}$ seed rate/ha might be due to inter-plant competition for the space, water, nutrient and light. As higher seed rate of $125 \mathrm{~kg} / \mathrm{ha}$, could not influence the LAI and light interception (Table 01). Tompkins et al., (1991) reported that the increase of seed rate from 65 to 400 seeds $/ \mathrm{m}^{2}$ increased grain yield because the higher number of kernels per spike obtained with the lower seed rates and was not able to compensate the low number of spikes per unit land.

The interaction was significant at Ludhiana in both the years and on a pooled mean basis. At Ludhiana, the highest grain yield was recorded in variety PBW 550 at a seed rate of $112.5 \mathrm{~kg} / \mathrm{ha}$ which was statistically on par with PBW 343 and DBW 17 at 100 and $125 \mathrm{~kg}$ seed rate/ha and PBW 550 at $125 \mathrm{~kg}$ seed rate/ ha in 2007-08. In 2008-09 and on the basis of pooled analysis, the highest grain yield of PBW 550 at seed rate of $112.5 \mathrm{~kg} /$ ha was statistically on par with only PBW 550 at 125 $\mathrm{kg}$ seed rate/ha. It might be due to higher ears/ square metre at this seed rate. Similar results by Black and Aase (1982) confirmed that URSS winter wheat cultivars had a greater ability to maintain high kernels per spike at high plant density compared to USA cultivars and, according to Marshall and Ohm (1987) and Anderson and Barclay (1991), the optimal plant population changes according to variety and local conditions. Carr et al., (2003) found that grain yield of wheat was higher with 250 than with 450 seeds $/ \mathrm{m}^{2}$.

However, no marked differences among varieties were observed in the response of grain yield to changing plant density (Carr et al., 2003). In central Europe and in Italy narrow row spacing, comprised between 12 and $18 \mathrm{~cm}$, and seed densities of about 400 seeds $/ \mathrm{m}^{2}$ are traditionally applied to wheat
(Ercoli and Masoni, 1995; Blankenau and Olfs, 2001), whereas densities around 250 seeds/ $\mathrm{m}^{2}$ and even lower are considered optimal for Canada and the United States (Read and Warder, 1982; Donaldson et al., 2001; Carr et al., 2003) which is also good for North Indian conditions (Anonymous 2010).

\section{Economics}

The highest gross, net returns and $\mathrm{B}: \mathrm{C}$ ratio was recorded in variety $\mathrm{PBW} 550$ which were statistically similar with DBW 17 but significantly higher than PBW 343 (Table 08). It might be due to higher grain yields observed in The seed rate of $112.5 \mathrm{~kg} / \mathrm{ha}$ was recorded the highest gross, net returns and $\mathrm{B}: \mathrm{C}$ ratio, it might be due to higher grain yield recorded than in $87.5 \& 100 \mathrm{~kg}$ seed rate/ha and lower cost of cultivation than $125 \mathrm{~kg}$ seed rate/ ha. Mehrvar and Asadi (2006) also reported higher returns in case of $110 \mathrm{~kg} / \mathrm{ha}$ seed rate in Iran. The gross, net returns and B:C ratio recorded in PBW 550 at $112.5 \mathrm{~kg}$ seed rate/ha was significantly higher than all other varieties at any of the seed rate. 
Table 08: Effect of varieties and seed rate on grain yield of wheat at different locations (pooled mean)

\begin{tabular}{|c|c|c|c|c|c|}
\hline \multirow{2}{*}{ Varieties } & \multicolumn{5}{|c|}{ Seed rate $(\mathrm{kg} / \mathrm{ha})$} \\
\hline & 87.5 & 100.0 & 112.5 & 125.0 & Mean \\
\hline & \multicolumn{5}{|c|}{ Gross returns ( $/$ ha) } \\
\hline PBW 550 & 52800 & 58190 & 63910 & 62260 & 59290 \\
\hline PBW 343 & 49280 & 50600 & 56760 & 49940 & 51645 \\
\hline DBW 17 & 50710 & 55880 & 55660 & 56210 & 54615 \\
\hline \multirow[t]{2}{*}{ Mean } & 50930 & 54890 & 58740 & 56100 & \\
\hline & \multicolumn{5}{|c|}{ Net returns ( $/ /$ ha) } \\
\hline PBW 550 & 37050 & 42190 & 47660 & 45760 & 43165 \\
\hline PBW 343 & 33530 & 34600 & 40510 & 33440 & 35520 \\
\hline DBW 17 & 34960 & 39880 & 39410 & 39710 & 38490 \\
\hline \multirow[t]{2}{*}{ Mean } & 35180 & 38890 & 42490 & 39600 & \\
\hline & \multicolumn{5}{|c|}{$\mathrm{B}: \mathrm{C}$ ratio } \\
\hline PBW 550 & 2.35 & 2.64 & 2.93 & 2.77 & 2.68 \\
\hline PBW 343 & 2.13 & 2.16 & 2.49 & 2.03 & 2.20 \\
\hline DBW 17 & 2.22 & 2.49 & 2.43 & 2.41 & 2.39 \\
\hline Mean & 2.23 & 2.43 & 2.61 & 2.40 & \\
\hline \multirow[t]{2}{*}{$\operatorname{LSD}(p=0.05)$} & & Pooled & & & \\
\hline & Gross returns & Net returns & $\mathrm{B}: \mathrm{C}$ ratio & & \\
\hline Varieties & 4710 & 4785 & 0.24 & & \\
\hline Seed rate & 5246 & 4868 & 0.25 & & \\
\hline Interaction & 5500 & 5218 & 0.21 & & \\
\hline
\end{tabular}

\section{CONCLUSION}

Based on the two years of experimentation it is concluded variety PBW 550 gave higher productivity than PBW 343 and DBW 17. The variety PBW 343 has now become susceptible to yellow rust and should not be cultivated especially in sub-mountainous region of
Indian Punjab. Seed rate of $100 \mathrm{~kg} / \mathrm{ha}$ was found to be optimum for PBW 343 and DBW 17 but seed rate of $112.5 \mathrm{~kg} / \mathrm{ha}$ for PBW 550 should be used to get highest productivity. The highest net returns recorded in variety PBW 550 at seed rate of $112.5 \mathrm{~kg} / \mathrm{ha}$.

\section{REFERENCES}

Anderson,W.K. and J. Barclay (1991). Evidence for differences between three wheat cultivars in yield response to plant population. Australian Journal of Agricultural Research, 42: 701-713.

Anonymous (2010). Punjab Agricultural University, Ludhiana, Punjab (India), Package of Practices for crops of Punjab- Rabi, 27:1-17. 
Anonymous (2012). Progress report of All India Coordinated Wheat and Barley Improvement Project 2011-12, Project Director's Report. Ed: Indu Sharma Directorate of Wheat Research, Karnal, India, pp: 74.

Arduini, I. A. Masoni, L. Ercoli and M. Mariotti (2009). Grain yield, and dry matter and nitrogen accumulation and remobilization in durum wheat as affected by variety and seeding rate. European Journal of Agronomy, 25: 309-318.

Aujla, S.S., Sharma, Y.R and G.S. Nanda (1986). Relative tolerance of wheat varieties to stripe and leaf rusts. Indian Phytopathology, 39: 46-49.

Bennett, F.G.A. and B. Westcott (1982). Field assessment of resistance to powdery mildew in mature wheat plants. Plant Pathology, 31: 261-268.

Bhardwaj, V., V. Yadav and B.S. Chauhan (2010). Effect of nitrogen application timings and varieties on growth and yield of wheat grown on raised beds. Archives of Agronomy and Soil Science, 56: 211-222.

Black, A.L. and J.K. Aase (1982). Yield component comparisons between USA and USSR winter wheat cultivars. Agronomy Journal, 74: 436-441.

Blankenau, K. and H.W. Olfs (2001). Effect of different crop densities of winter wheat on recovery of nitrogen in crop and soil within the growth period. Journal of Agronomy and Crop Science, 186: 151-156.

Carr, P.M., R.D. Horsley and W.W. Poland (2003). Tillage and seeding rate effects on wheat cultivars. I. Grain production. Crop Science, 43: 202-209.

Chaudhary R.C., S. S. Aujla, I. Sharma and J.S.Samra (1985). Perpetuation of black point pathogen of wheat and factors affecting the disease incidence. Indian Journal of Ecology, 12: 133-137.

Coventry, D.R., T.G. Reeves, H.D. Brooke, and D.K. Cann (1993). Influence of genotype, sowing date, and seeding rate on wheat development and yield. Australian Journal of Experimental Agriculture, 33:751-757.

Donaldson, E., F.W. Schillinger and S.M., Dofing (2001). Straw production and grain yield relationships in winter wheat. Crop Science, 41: 100-106.

Ercoli, L. and A. Masoni (1995). Effects of row spacing and orientation on yield and yield components of winter wheat. Agricultural Medicine. 125:215-221.

Fowler, D.B., J. Brydon, B.A. Darroch, M.H. Entz, and A.M. Johnston (1990). Environment and genotype influence on grain protein concentration of wheat and rye. Agronomy Journal, 82:655-664.

Fowler, D.B. (2003). Crop nitrogen demand and grain protein concentration of spring and winter wheat. Agronomy Journal, 95:260-265. 
Hobbs, P.R., and K.D. Sayre (2001). Managing experimental breeding trials. In E.H. Reynolds, J.L., Ortiz-Monasterio and A. McNad (ed.) Application of physiology to wheat breeding. CIMMYT, Mexico, D.F., Mexico.

Lloveras, J., J. Manent, J. Viudas, A. Lopez and P. Santiveri (2004). Seeding rate influence on yield and yield componenets of irrigated winter wheat in Mediterranean climate. Agronomy Journal, 96: 1258-1265.

Marshall, G.C. and H.W. Ohm (1987). Yield responses of 16 winter wheat cultivars to row spacing and seeding rate. Agronomy Journal, 79: 1027-1030.

Mehrvar, M.R. and H. Asadi (2006). Agronomical and economical assessment of planting methods and seeding rates. Journal of Agronomy, 5: 626-633.

Ozturk, A., O. Caglar and S Bulut (2006). Growth and yield response of facultative wheat to winter sowing, freezing sowing and spring sowing at different seeding rates. Journal of Agronomy and Crop Science, 192: 10-16.

Petersen, R.F., A.B., Canpbell and A.E. Hannals (1948). A diagrammatic scale for estimation rust intensities of leaves and stem of cereals. Canadian Journal of Research, 26:496-500.

Ram H., Yadvinder-Singh, Saini, K. S., Kler, D. S., Timsina, J. and E. J. Humphreys (2012). Agronomic and economic evaluation of permanent raised beds, no tillage and straw mulching for an irrigated maize-wheat system in northwest India. Experimental Agriculture, 48:21-38.

Read, D.W.L. and F.G. Warder (1982). Wheat and barley responses to rates of seeding and fertilizer in Southwestern Saskatchewan. Agronomy Journal, 74: 33-36.

Saleem, M.F., B.L.Ma, H. Voldeng and T.C. Wang (2010). Nitrogen nitrition on leaf chlorophyll, canopy reflectance, grain protein and grain yield of wheat varieties with contrasting grain protein content. Journal of Plant Nutrition, 33: 1681-1695.

Sharma I., G.S. Nanda, P.K.Kaloty and A.S. Grewal (1998). Prevalence of Karnal bunt disease of wheat in Punjab. Seed Research, 26: 155-160.

Singh, S.S., R. Yadav, G.P. Singh and N. Jain (2009). Wheat- The rop of past, present and future generations. Indian Farming, (December 2009) : 6-11.

Staggenborg, S.A., D.A. Whitney, D.L. Fjell, and J.P Shroyer (2003). Seeding and nitrogen rates required to optimize winter wheat yields following grain sorghum and soybean. Agronomy Journal, 95:253-259.

Tompkins, D.K., A.T. Wright, and D.B Fowler (1992). Foliar disease development in no-till wheat: Influence of agronomic practices on powdery mildew development. Canadian Journal Plant Science, 72: 965-972.

Tompkins, D.K., D.B. Fowler and A.T., Wright (1991). Water use by no-till winter wheat. influence of seed rate and row spacing. Agronomy Journal, 83: 766-769. 
Whaley, J.M., D.L Sparkes, M.J. Foulkes, J.H. Spink, T. Semere and R.K. Scott (2000). The physiological response of winter wheat to reductions in plant density. Annals of Applied Biology, 137: 165-178.

Wiersma, J.J. (2002). Determining an optimum seeding rate for spring wheat in Northwest Minnesota. Available at www.plantmanage mentnetwork.org/cm/. Crop Manage. doi:10.1094/CM-2002-0510- 01-RS. 